\title{
A Responsabilidade Civil do Estado e o Dano Moral
}

\section{Jair José Perin}

\section{INTRODUÇÃO}

A responsabilidade civil do Estado, no decorrer da evolução do direito, passou por diversas fases, começando por aQuela em que o Estado não podia ser responsabilizado por QualQuer lesão ao direito de alguém, já Que na concepção absolutista, o Estado não estava na mesma relação das pessoas físicas e jurídicas, mas sim acima. Essa fase da irresponsabilidade perdurou praticamente durante todo o decorrer do século XIX.'

Passou, posteriormente, para a fase da responsabilidade civilista, surgida na França no século XIX, Quando da discussão sobre a conceituação de atos de império e de gestão, em Que começou a ser firmada a responsabilidade da administração pública por danos provenientes de atos de gestão, no caso de culpa ou dolo do agente público.

Como evolução da teoria da responsabilidade civilista, passa-se para a fase da publicização da culpa administrativa, criação do Conselho de Estado francês. Esta teoria inova profundamente, pois se passa para a responsabilidade do Estado independentemente da falta do agente público, Quando originária da Administração, pelo mau funcionamento do serviço público ou pela sua inexistência, cuja decorrência deve ser concretamente avaliada e analisada. Esta fase marca a transição para a atual fase da responsabilidade objetiva do Estado. O fato Que materializou esta nova concepção foi o julgamento do caso Blanco em I 873, na França, em Que somente as regras de direito público foram aceitas para a solução do caso, porQuanto o Estado aparecia como causador de dano a administrado. Nesse tipo de responsabilidade, a idéia culpa é substituída pela de nexo de causalidade, entre o funcionamento do serviço público e o prejuízo sofrido pelo administrado. É indiferente que o serviço público tenha funcionado bem ou mal, de forma regular ou irregular. Não há necessidade de apreciação do dolo ou culpa. É a chamada teoria do risco, porquanto tem como pressuposto de eue a atuação do poder público envolve um risco de dano, Que lhe é ínsito.

I PIETRO, Maria Sylvia Zanella Di. Direito administrativo. 10. ed. São Paulo: Atlas, 1999, p. 418-43I. 
Pela teoria do risco objetivo, figura o entendimento de que ao lesado não interessa conhecer o responsável pelo dano, ele almeja o ressarcimento, desde que estabelecido o nexo causal entre ele e o Estado. ${ }^{2}$

Observa-se que a teoria do risco envolve duas modalidades: a do risco administrativo, caracterizada esta por admitir as causas excludentes da responsabilidade do Estado: culpa da vítima, culpa de terceiros, caso fortuito ou força maior; e do risco integral, a Qual não admite as excludentes aceitas pela teoria do risco administrativo. ${ }^{3}$

\section{DIFERENÇA ENTRE RESPONSABILIDADE CIVIL SUBJETIVA E OBJETIVA}

Na responsabilidade civil subjetiva verifica-se que estão presentes a ação ou omissão voluntária, relação de causalidade ou nexo causal, dano e, finalmente, culpa. A ação ou omissão, para gerar responsabilidade subjetiva, deve estar calcada, respectivamente, na prática de um ato Que não se deva efetivar ou na não observância de um dever de agir. A relação de causalidade é o vínculo cue une a conduta do agente ao dano, sendo Que inexistindo este não haverá possibilidade de indenização do ato ilícito. A culpa civil abrange não somente o ato ou conduta intencional, mas também os atos ou condutas eivados de negligência, imprudência ou imperícia, a culpa em sentido estrito (Quase delito). ${ }^{4}$

Por outro lado, a responsabilidade objetiva desconsidera a culpabilidade e imputablidade, bastando ser constatada a existência dos requisitos de causalidade e dano. Aqui o sujeito é responsável, por força de previsão legal, pelos riscos ou perigos Que sua atuação promover, ainda Que colocada toda diligência para evitar o dano. Apenas ficará afastada a responsabilidade caso houver culpa exclusiva da vítima, força maior, caso fortuito e fato de terceiro, haja vista Que nesses casos há impedimento da concretização do nexo causal. ${ }^{5}$

Vigora, com prevalência, no nosso ordenamento jurídico a regra geral de Que o dever ressarcitório pela prática de atos ilícitos decorre da culpa, ou seja, da reprovabilidade ou censurabilidade da conduta do agente. O comportamento do agente será reprovado ou censurado Quando, ante circunstâncias concretas do caso, se entende que ele poderia ou deveria ter agido de modo diferente. $O$ ato ilícito Qualifica-se pela culpa. Nầo havendo culpa, não haverá, em regra, Qualquer responsabilidade. À luz do art. 186 do Código Civil, ocorre

2 VENOSA, Silvio de Salvo. Direito civil. Contratos em espécie e responsabilidade civil. São Paulo: Atlas, 2001, p. $497-533$

3 MEIRELLES, Hely Lopes. Direito administrativo brasileiro. 22. ed. Sáo Paulo: Malheiros, 1997, p. 560 573.

4 VENOSA, Silvio de Salvo. Op. cit., p. 497-533.

$s$ Ibidem. 
ato ilícito Quando alguém, por ação ou omissão voluntária, negligência ou imprudência, violar direito ou causar dano, ainda que exclusivamente moral, a outrem, em face do que será responsabilizado pela reparação dos prejuízos. ${ }^{6}$

Em virtude da constatação de Que, em alguns casos, havia a necessidade de evolução em termos de responsabilidade civil, a fim de melhor atender aos reclamos da sociedade, seja por motivo de avanços tecnológicos, seja por outras razões, a legislação começou a prever e contemplar a responsabilidade civil sob o enfoque da teoria do risco, ou seja. independentemente da existência de culpa. Com a materialização do dano, o causador deste deverá indenizar, por imposição legal, mesmo que não tenha agido com dolo ou culpa estrito senso. A vítima apenas deverá provar o nexo de causalidade, o dano e a autoria, sem Que se investigue em relação a esta pessoa a sua conduta dolosa ou culposa. Portanto, a responsabilidade objetiva calca-se, funda-se e justifica-se no risco. ${ }^{7}$

No caso da responsabilidade objetiva do Estado, o risco é suportado de forma repartida entre todos os cidadãos. O princípio da igualdade impera, poreuanto os prejuizos a alguns particulares causados pelas pessoas jurídicas de direito público advindos de suas atividades em prol de toda a sociedade devem ser suportados por essa mesma coletividade de forma isonômica. Evita-se, assim, Que algumas pessoas integrantes da coletividade politicamente organizada sejam oneradas mais do Que outras. A responsabilidade civil do Estado está prevista pelo direito civil e direito público, este com prevalência, seja no ramo do direito constitucional, como no do direito administrativo e no do direito internacional público. ${ }^{8}$

\section{FUNDAMENTO ATUAL DA RESPONSABILIDADE OBIETIVA DO ESTADO}

A Constituição atual da República Federativa do Brasil adotou a teoria da responsabilidade objetiva, na modalidade do risco administrativo. $O$ art. $37, \S 6^{\circ}$, dispõe:

As pessoas jurídicas de direito público e as de direito privado prestadoras de serviços públicos responderão pelos danos Que seus agentes, nessa qualidade, causarem a terceiros, assegurado o direito de regresso contra o responsável nos casos de dolo ou culpa.?

A responsabilidade objetiva do Estado adotada pela Constituição Federal está assentada na teoria do risco administrativo. Havendo dano causado pela administração pública em face da vítima, esta terá direito à reparação, mesmo que não exista culpa daquela. Somente ficará afastada essa responsabilidade se administração pública conseguir provar culpa exclusiva da vítima, caso fortuito e força maior; atenuação haverá se houver culpa

DINIZ, Maria Helena. Curso Direito Civil Brasileiro. São Pauło: Saraiva, 2003, v. 17, p. 40.

Ibidem.

8 DINIZ, Maria Helena.Op, cit., p. 40.

9 BRASIL. Constituiçäo (1988). 4. ed. Rio de laneiro: DP\&A Editora, 1999. 
concorrente. A teoria do risco administrativo centra-se, alicerça-se, em cima do risco que a atividade pública pode produzir para os administrados e na possibilidade de acarretar dano a certos membros da comunidade, impondo-mes um ônus não suportado pelos demais. Para compensar os administrados prejudicados, os demais integrantes dessa comunidade. dentro do princípio da solidariedade e de justiça distributiva, concorrem para a reparação do dano, por intermédio da Fazenda Pública. ${ }^{10}$

De acordo com o dispositivo constitucional, as entidades estatais e seus desmembramentos administrativos, bem como as pessoas físicas e jurídicas, sejam entidades paraestatais, ou concessionárias e permissionárias, Que exerçam funções públicas delegadas, respondem pelos danos causados a terceiros por seus agentes, independentemente da prova de culpa no cometimento da lesão. Para a indenização dos atos e fatos estranhos à atividade administrativa observa-se o princípio geral da culpa civil, manifestada pela imprudência, negligência ou imperícia na realização do serviço público que causou ou ensejou o dano."

Existe a possibilidade de o Estado, caso condenado a indenizar o administrado, ingressar com ação regressiva, de rito ordinário, nos termos do Código de Processo Civil, contra o agente público, caso este tenha sido o responsável, por dolo ou culpa, pela condenação do Ente Público. Para ajuizar essa ação, portanto, há a necessidade de prévia condenação da pessoa estatal à indenização de terceiros por ato lesivo do agente, e anterior constatação, em processo regular, onde sejam respeitados todos os princípios do devido processo legal, do comportamento doloso ou culposo do agente. ${ }^{12}$

A Lei $n^{\circ} 8.112$, de 11 de dezembro de 1990, Que dispõe sobre o Regime lurídico dos Servidores Públicos, confirma o exposto Quando expressa:

Art. 122. A responsabilidade civil decorre de ato omissivo ou comissivo, doloso ou culposo, Que resulte em prejuízo ao erário ou a terceiro.

$\S 2^{\circ}$ Tratando-se de dano causado a terceiros, responderá o servidor perante a Fazenda Pública, em ação regressiva.

\section{A DESNECESSIDADE DA DENUNCIAÇÃO DA LIDE E A AÇÃo REGRESSIVA}

Em consonância com a posiçāo majoritária da doutrina e da jurisprudência, näo mais é obrigatória, e nem aceitável, a denunciação da lide nos termos do art. 70, III, do CPC, na própria ação indenizatória, para funcionar como o direito de regresso. A razão para a sustentação desse entendimento reside no fato de Que na ação indenizatória baseada na responsabilidade objetiva do Estado, segundo a teoria do risco administrativo, somente é

\footnotetext{
10 Ibidem.

"I MEIRElles, Hely lopes. Op. cit., p. 562-563.

12 PiETRO, Maria Sylvia Zanella Di. Op cit., p. 430-431.
} 
afastada a responsabilidade do Ente Estatal caso este prove a culpa exclusiva da vítima, de terceiros, caso fortuito ou força maior. Não existe, por extensão, espaço nessa relação processual para discutir a culpa ou o dolo do agente público que porventura tenha sido o causador do dano. ${ }^{13}$

O não cabimento de denunciação da lide no caso em Que o Estado deve responder de forma objetiva, na modalidade do risco administrativo, reside, portanto, no fato de que o agente causador do dano responde à luz da responsabilidade civil subjetiva por meio da prova do dolo ou culpa. Assim, a admissão da denunciação da lide desvirtuaria o instituto da responsabilidade objetiva. ${ }^{14}$

A respeito, veja-se as seguintes jurisprudências:

CONSTITUCIONAL. Responsabilidade Civil do Estado. Seus pressupostos. 2) Processual Civil. A ação de indenização, fundada na responsabilidade objetiva do Estado, por ato de funcionário (Constituição, Art. 107 e parágrafo único), não comporta obrigatoriamente denunciação a este, na forma do art. 70, III, do Código de processo Civil, para apuração de culpa, desnecessária a satisfação do prejudicado. ${ }^{15}$

PROCESSUAL CMIL. AGRAVO DE INSTRUMENTO. ART. 70, III, DO CPC. AÇÃO DE INDENIZAÇÃO. RESPONSABILIDADE OBJETIVA DO ESTADO. DENUNCIAÇÃO À LIDE DO AGENTE PÚBLICO PRETENSAMENTE CAUSADOR DO DANO. DESNECESSIDADE. TEORIA OBIETIVA ABARCADA PELA CONSTITUIÇÃO FEDERAL.

Tendo a Constituição Federal abarcada a teoria objetiva da responsabilidade, todo dano ocasionado ao particular, por servidor público, há de ser ressarcido, independentemente da existência de dolo ou culpa deste. Assim, pela via oblíqua, forçoso é de se concluir que a denunciação à líde, in casu, embora recomendável, é desnecessária à satisifação do direito do prejudicado, e não afasta a possibilidade de o denunciante requerer o direito alegado, posteriormente, na via própria, haja vista não ter o art. 70, inc. Ill, do Estatuto Processual Civil, norma do direito instrumental, o poder de aniquilar o próprio direito material. Precedentes. Agravo regimental improvido. ${ }^{16}$

13 MELLO. Celso Antonio Bandeira de. Curso de Direito Administrativo. São Paulo: Matheiros, 1997. p. 642-644.

If ANJOS. Luís Henrique Martins dos; IONE. Walter. Manua/ de Direito Administrativo. Porto Alegre: Livraria do Advogado, 2001, p. 356.

is Supremo Tribunal Federal, RE- 93880/RI, Segunda Turma, Relator Ministro Décio Miranda, Dj 05.02.82, p. 10443.

16 Superior Tribunal de Justiça, Segunda Turma, Decisão de 20/11/2001, Agravo Regimental no Agravo de instrumento - 396230, Processo $\mathrm{n}^{\circ}$ 2001.00.82346-0/BA 


\section{ADMINISTRATIVO. PROCESSO CIVIL. AGRAVO RETIDO. DENUNCIAÇÃO A LIDE. ACIDENTE DE AUTOMÓVEL. RESPONSABILIDADE OB|ETIVA DO ESTADO. INDENIZAÇÃO. LUCROS CESSANTES.}

I. Em ação de responsabilidade civil por ato omissivo ou comissivo do servidor da pessoa jurídica de direito público, a denunciação da lide pode ser indeferida pelo juiz. Nessa ação, incumbe ao autor provar a ocorrência do fato lesivo e o dano daí decorrente. A culpa do servidor nāo é discutida. A Constituição Federal assegurou a pessoa de direito público a ação de regresso, independente de denunciar a lide.

2. Abalroando o motorista do carro oficial, por não atentar para as condições de tráfego, no momento, o veículo (táxi), Que trafegava pela faixa Que ihe era própria, em situação regular, responde o Estado pela indenização.

3. Tendo o automóvel, táxi, permanecido parada, na oficina, para conserto, impossibilitando o seu proprietário de auferir renda com a sua utilização, obrigado está o Estado a pagar os lucros cessantes.

4. Agravo retido e apelação improvidos. ${ }^{17}$

DIREITO ADMINISTRATNO. REPARAÇÃO DE DANOS DECORRENTES DE COLISÃO DE MOTOCICLETA COM VATURA DO EXÉRCITO BRASILEIRO. RESPONSABILIDADE OBJETIVADA UNIÃO. DENUNICAÇÃO DAUDE DOS MILITARES RESPONSÁVEIS. INVABILIDADE.

A denunciação à lide dos militares envolvidos no acidente implicaria em evidente prejuízo ao apelado, pois procrastinaria o reconhecimento de um legítimo direito da vítima, em razão da responsabilidade objetiva do Estado. fazendo com Que dependa de solução de um outro conflito intersubjetivo de interesses, entre o Estado e os militares. ${ }^{18}$

De acordo com o doutrinador Humberto Theodoro Júnior, pela sistemática do Código de Processo Civil, a denunciação da lide é medida obrigatória, Que leva a uma sentença sobre a responsabilidade de terceiro em face do denunciante, de par com a solução normal do litígio de início deduzido em juízo, entre autor e réu. Consiste em chamar o terceiro (denunciado), Que mantém um vínculo de direito com a parte (denunciante), para vir responder pela garantia do negócio jurídico, caso o denunciante saia vencido no processo. ${ }^{19}$

17 Tribunal Regional Federal da $1^{2}$ Regiäo, Terceira Turma, Relator Juiz Tourinho Neto, Apelaçäo Cível no Processo $n^{2}$ 1989.01.09213-1/DF, publicado no D| 04/06/1990, p. 11755.

18 Tribunal Regional Federal da $4^{2}$ Regiăo, Terceira Turma, Rełatora luíza Luíza Dias Cassales, Apelação Cível no Processo na 94.04.39728-8/RS, publicado no D/ DE 14/10/1998, p. 580.

19 THEODORO júNiOR, Humberto. Curso de direito processual civil. 20. Ed. Rio de Janeiro: Forense, 1997. 
Como se vê, existe substancial diferença entre a denunciação da lide prevista na Lei Processual brasileira e a ação regressiva constante no art. $37, \S 6^{\circ}$ da Carta da República Federativa do Brasil, haja vista Que nesta, primeiro o Poder Público responde objetivamente à luz da teoria do risco administrativo, e caso condenado, em provando a culpa ou dolo do agente público, ingressa com uma ação contra este. ${ }^{20}$

\section{O AMPARO PARA O DANO MORAL E A RELATIVIDADE DO DIREITO}

Feitas as considerações acima, cabe enfrentar a problemática da indenização por dano moral frente à atual sistemática de processamento dos pedidos de indenização por danos decorrentes da responsabilidade objetiva agasalhada pelo texto constitucional.

A Constituição Federal de 1988, refletindo a evolução do direito nacional e internacional em relação ao ser humano como indivíduo em si, ou considerado coletivamente, garantiu a inviolabilidade de direitos Que o Poder Constituinte Originário reconheceu como essenciais, os Quais, na sua grande maioria, encontram-se arrolados no art. $5^{\circ}$. Esses direitos fundamentais fazem parte daquele núcleo constitucional imodificável e inatingivel pelo Poder Derivado, seja por intermédio de emenda constitucional, ou outro modo de reforma da Constituição Federal, porquanto constituem cláusulas pétreas nos termos do $\S 4^{\circ}$ do art. 60 . Somente por meio de outro poder constituinte originário isso será possível, o Que não deverá ocorrer, com certeza, haja vista constituir direitos con@uistados pela própria evolução da humanidade e dos estados politicamente organizados, principalmente dos estados democráticos de direito.

Como forma de garantir e dar efetividade à inviolabilidade dos direitos fundamentais consagrados constitucionalmente a Constituição Federal prevê, além de outros, a possibilidade de ser pleiteada a indenizabilidade não só do dano patrimonial, mas também do dano moral. Os incisos V eX do art. $5^{\circ}$ da Constituição Federal ${ }^{21}$ dispõem, respectivamente:

é assegurado o direito de resposta, proporcional ao agravo, além de indenização por dano material, moral ou à imagem; [...]

são invioláveis a intimidade, a vida privada, a honra e a imagem das pessoas, assegurado o direito a indenização pelo dano material ou moral decorrente de sua violação.

Por estarem previstos no art. $5^{\circ}$ da Constituição da República Federativa do Brasil, são considerados direitos fundamentais, aos quais deve ser dado o máximo de concretização

${ }^{20}$ ANJOS. Luís Henrique Martins dos; IONE. Walter. Op. cit., p. 355-356.

24 BRASIL. Constituição. 4. ed. Rio de laneiro: DP\&A Editora, 1999. 
material, já que desfrutam de aplicabilidade imediata, de acordo com o expresso no parágrafo primeiro deste artigo. Cabe aqui trazer as considerações do doutrinador José Afonso da Silva ${ }^{22}$, a respeito da aplicabilidade e eficácia das normas que contêm os direitos fundamentais. Assim leciona:

A eficácia e aplicabilidade das normas Que contêm os direitos fundamentais dependem muito de seu enunciado, pois se trata de assunto que está em função do Direito positivo. A Constituição é expressa sobre o assunto, Quando estatui que as normas definidoras dos direitos e garantias fundamentais têm aplicação imediata. Mas certo é Que isso não resolve todas as Questôes, porQue a Constituição mesma faz depender de legislação ulterior a aplicabilidade de algumas normas definidoras de direitos sociais, enquadrados dentre os fundamentais. Por regra, as normas Que consubstanciam os direitos fundamentais democráticos e individuais são de eficácia contida e aplicabilidade imediata, enquanto as que definem os direitos econômicos e sociais tendem a sê-lo também na Constituição vigente, mas algumas, especialmente as Que mencionam uma lei integradora, são de eficácia limitada, de princípios programáticos e de aplicabilidade indireta, mas são tão jurídicas como as outras e exercem relevante função, porQue, Quanto mais se aperfeiçoam e adQuirem eficácia mais ampla, mais se tornam garantias de democracia e do efetivo exercício dos demais direitos fundamentais.

Esses direitos Fundamentais consagrados na Constituição Federal exigem do Estado, por vezes, uma atuação negativa, no sentido de não agredir e/ou desrespeitar a esfera individual da pessoa ou da coletividade considerada, e, em outras situações, uma atitude positiva para dar concretude às expectativas das pessoas e da sociedade.

Essas previsões constitucionais colocaram por terra todas vacilações Que havia na doutrina e na jurisprudência a respeito do cabimento ou não de indenização por dano moral. O dano moral, diversamente do dano material Que é concreto, é mais sutili, em virtude de que envolve ataques aos sentimentos humanos, como a honra, a dignidade e a reputaçáo.

Porém, essa previsão constitucional da possibilidade de ser pleiteada a indenização por dano moral, Quando houver violação à intimidade, à vida privada, à honra e à imagem das pessoas, não pode ser encarada de forma simplista, devendo ser levado em consideração diversos fatores, valores em conflito e circunstâncias envolventes, a fim de ser um instrumento de aceitação e de resignação por toda a sociedade.

Há Que se ter presente Que a Constituição Federal impōe ao Estado e à sociedade o dever de garantir não somente os direitos de primeira geração (a vida, a liberdade, associação etc.), mas também os de segunda (o direito ao trabalho, à saúde e à educação etc.), e de

22. SiLVA. José Afonso da. Curso de direito constitucional positivo. 13 ed. São Paulo: Malheiros, 1997. 
terceira (direito ao desenvolvimento, à paz, ao meio ambiente etc.); ou seja, houve um abandono da idéia individualista, passando a existir uma inquietude social mais abrangente. Isso demanda, efetivamente, para o Estado uma preocupação global, a fim de não ocorrer maior valorização de determinados direitos en prejuízo de outros. Logicamente que a viabilização dos direitos de segunda, terceira, e até de Quarta geração, estes reconhecidos por apenas alguns doutrinadores, refletem diretamente sobre os de primeira geração, como estes, também, repercutem en relação às demais gerações de direitos. Na verdade, percebese Que existe uma verdadeira interação e interdependência nessas geraçōes de direitos.

O doutrinador Alexandre de Moraes nos traz as seguintes lições: ${ }^{23}$

Os direitos e garantias fundamentais consagrados pela Constituição Federal, portanto, não são ilinitados, uma vez Que encontran seus limites nos demais direitos iguaimente consagrados pela Carta Magna (Princípio da refatividade ou convivência das liberdades públicas).

Desta forma, Quando houver conflitos entre dois ou mais direitos ou garantias fundamentais, o intérprete deve utilizar-se do princípio da concordância prática ou da harmonização de forma a coordenar e combinar ou bens jurídicos em conflito, evitando o sacrificio total de uns em relação aos outros, realizando uma redução proporcional do âmbito de alcance de cada Qual (contradição dos princípios). sempre em busca do verdadeiro significado da norma e da harmonia do texto constitucional com sua finalidade precípua.

Apontando a relatividade dos direitos fundamentais, Quiroga Lavie afirma Que os direitos fundamentais nascem para reduzir a ação do Estado aos limites impostos pela Constituição, sem, contudo desconhecerem a subordinação do indivíduo ao Estado, como garantia de que eles operem dentro dos limites impostos pelo direito.

À própria Declaração dos Direitos Humanos das Nações Unidas, expressamente, em seu art. 29 afirma Que:

toda a pessoa tem deveres com a comunidade, posto que somente nela pode desenvolver livre e plenamente sua personalidade. No exercício de seus direitos e no desfrute de suas liberdades todas as pessoas estarão sujeitas às limitaçôes estabelecidas pela lei com a única finalidade de assegurar o respeito dos direitos e liberdades dos demais, e de satisfazer as justas exigências da moral, da ordem pública e do bem-estar de uma sociedade democrática. Estes direitos e lịberdades não podem, em nenhum caso, serem exercidos em oposição com os propósitos e princípios das Nações Unidas. Nada na presente Declaração poderá ser interpretado no sentido de conferir direito algum ao Estado, a un grupo ou uma pessoa, para empreender e desenvolver atividades ou realizar atos tendentes à supressão de Qualquer dos direitos e liberdades proclamados nessa Declaração.

${ }^{23}$ MORAES, Alexandre de. Direito constitucional. 5.ed. São Paulo: Atlas, 1999. 
O advogado Mário Lúcio Quintão Soares nos reporta:24

A Constituiçâao brasileira, procurando ser um instrumento de mudança social, preconiza, expressamente, princípios basilares de direitos humanos, como: soberania, cidadania, dignidade humana e valores sociais do trabalho; a construção de uma sociedade justa, livre e solidária; a erradicação da pobreza e da marginalização social; a prevalência dos direitos humanos nas relações internacionais.

A Carta Magna evoluiu ideologicamente em relação às Constituições anteriores, mesmo a liberal de 1946, ampliando as garantias constitucionais aos direitos individuais e coletivos contemplados, estabelecendo um capítulo específico e moderno para os direitos sociais e introduzindo os direitos fundamentais de terceira geração, dispondo inclusive, no artigo 225, sobre o "direito ao meio ambiente ecologicamente equilibrado.

Ocorreu incontestável avanço na abordagem dos direitos fundamentais, Que devem integrar-se em uma justaposição harmônica, evitando a deformaçăo individualista, para abranger o rol de todos os direitos Que devem ser reconhecidos ao cidadão e ao homem.

Portanto, referente à ação de indenização por dano moral Quando o Estado agride os direitos fundamentais, a honra, a imagem, a vida privada e a intimidade, deve ocorrer o máximo de cuidado na apuração do dano efetivo, à sua extensão, às suas circunstâncias, e outros aspectos relevantes, a fim de não haver um atropelo à necessária harmonia com os demais direitos e princípios que precisam ser assegurados pelo Poder Público. Cabe trazer a seguinte jurisprudência a respeito:

DANO MORAL. Necessariamente ele não existe pela simples razão de haver um dissabor. A prevalecer essa tese, Qualquer fissura de contrato daria ensejo ao dano moral conjugado com o material. O direito veio para viabilizar a vida e não para truncá-la, gerando-se um clima de suspense e de demandas. Ausência de dano moral, no caso concreto. Recurso desprovido. ${ }^{25}$

Maria Helena Diniz observa Que o dano moral não é a dor, a angústia, o desgosto, a aflição espiritual, a humilhação, o complexo Que sofre a vítima do evento danoso, pois estes estados de espírito constituem conteúdo, ou melhor, a consęüência do dano. O direito não repara Qualeuer padecimento, dor ou aflição, mas aQueles Que forem decorrentes da privação de um bem jurídico sobre o Qual a vítima teria interesse reconhecido juridicamente. ${ }^{26}$

${ }^{24}$ SOARES. Mário Lúcio Quintão. Direitos fundamentais do homern nos textos constitucionais brasileiro e alemão. Revista de Informação Legislativa, Brasília, n. 115, 1992.

25 AC ñ 596185181-RS, Sexta Câmara Cível, Rel. Desembargador Décio Antônio Erpen, julgamento 05.11 .96 .

${ }^{26}$ DiNiz, Maria Helena. Op. cil., p. 84-86. 
O doutrinador Silvio de Salvo Venosa consigna que "dano moral é o prejuízo que afeta o ânimo psíquico, moral e intelectual da vítima. Nesse campo, o prejuízo transita pelo imponderável, daí por que aumentam as dificuldades de se estabelecer a justa recompensa pelo dano. Em muitas situações, cuida-se de indenizar o inefável. Não é também QualQuer dissabor comezinho da vida Que pode acarretar a indenização." ${ }^{27}$

O Advogado Álvaro Couri Antunes Souza ${ }^{28}$ para definir danos morais usa as palavras dos doutrinadores Carlos Alberto Bittar e Wilson Mello da Silva que consignam, respectivamente: "danos morais são lesões sofridas pelas pessoas, físicas ou jurídicas, em certos aspectos de sua personalidade, em razão de investidas injustas de outrem. São aqueles que atingem a moralidade e a afetividade da pessoa, causando-lhe constrangimentos, vexames, dores, enfim, sentimentos e sensações negativas".

"Dano moral é aquele que diz respeito às lesões sofridas pelo suịeito físico ou pessoa natural (não jurídica) em seu patrimônio de valores exclusivamente ideais, vale dizer, não econômicos."

Em artigo publicado no lornal Zero Hora de 10.10.98, sob o título "A Indústria do Dano Moral", o Desembargador Décio Antônio Erpen, do Tribunal de lustiça do Estado do Rio Grande do Sul, assim expressa:

De outro lado, a seara jurídica fomenta, hoje, um instituto que, igualmente, instabiliza o próprio direito. Refiro-me à indústria do dano moral.

Sem uma definição científica do que seja, realmente, o dano moral, sem uma norma estabelecendo as áreas de abrangência e, sem parâmetros legais para a sua Quantificação, permite-se o perigoso e imprevisível subjetivismo do pleito, colocando o juiz numa posição de desconforto. Ele Que deve ser o executivo da norma, passou a personalizá-la.

A prevalecer o instituto sem critérios legais definidos, os profissionais, em especial os prestadores de serviço, exercerão seu mister com sobressalto; os produtores não resistirão às indenizaçôes de valores imprevisíveis. Sequer as seguradoras assumirão a cobertura ante a ausência de um referencial para a elaboração dos cálculos. Enfim, toda a sociedade estará submetida ao subjetivismo, o Que conspira contra um valor supremo do direito, a segurança jurídica.

¿ VENOSA. Silvio de Salvo. Op. cit., p. 514-515.

${ }^{28}$ SOUZA. Álvaro Couri Antunes. O Valor da causa nas açóes indenizatórias por danos morais. Revista dos Tribunais, jan. 2001, v. 783 . 
A corrente belicosa, se vitoriosa, gerará uma sociedade intolerante, na Qual se promoverá o ódio, a rivalidade, a busca de vantagens sobre outrem ou até a exaltação ao narcisismo. A promissora indústria do dano levará a esse triste Quadro $[\ldots] .{ }^{29}$

\section{A INCOMPATIBILIDADE DA TEORIA DA RESPONSABILIDADE OBJETIVA FRENTE AO DANO MORAL (TEORIA SUBJETIVA)}

Percebe-se, sob a ótica supracitada, Que a responsabilidade do Poder Púbilico Quanto ao dano moral, necessita passar por uma avaliação subjetiva, a fim de levantar com detalhes o grau de culpa ou de dolo do agente público causador do dano, bem como da vítima.

Quando envolver um agente público como vítima de dano causado por outro agente do Estado, o cuidado na avaliação do dano moral necessita aumentar ainda mais, devendo chegar, na maioria dos casos, a não existir, porquanto, na grande soma dos casos, o agente é vítima de outro agente que está envolvido diretamente nas circunstâncias Que o fato ocorreu. Para exemplificar, tomemos a atividade policial e militar, onde estes agentes assumem, ao tomarem posse nos cargos e funções, riscos inerentes à sua profissão, tais como, periculosidade, insalubridade e penosidade muito acentuados, onde o limite entre a culpa ou dolo do poder Público, por intermédio de seus outros agentes, e o próprio risco da atividade em si é muito tênue, exigindo do Poder Judiciário, Quando da prestação jurisdicional, muita parcimônia e sopesamento de todos esses fatos envolvidos. Geralmente, nesses casos, ocorre, também, uma compensação dos próprios bens protegidos constitucionalmente. Suponhamos que um agente policial, numa perseguição a bandidos, venha a ser alvejado por outro agente policial envolvido na operação, resultando no seu passamento. A sua família poderá ingressar com uma ação por dano moral, alegando a violação a algum bem protegido constitucionaimente.

Ocorre Que, simultaneamente, outros bens imateriais (por exemplo, a honra e a imagem), certamente, estarão em jogo, os Quais, no final da eQuação, ficarão numa posição de realce a dignificar essa vítima e sua família.

Pode-se dizer que existe uma incompatibilidade evidente entre a forma de apuração da responsabilidade objetiva patrimonial, com aQuela Que deve nortear a investigação em relação ao dano moral, onde nesta, os aspectos subjetivos devem ser muito bem provado e sopesados, eneuanto que naquela o Poder Público somente se exime de responsabilidade da indenização caso consiga provar a culpa exclusiva da vítima, de terceiro, força maior ou caso fortuito.

2 ERPEN. Décio Antônio. A indústria do dano moral, Zero Hora, Porto Alegre, 10 out. 1998. 
A prova da culpa ou do dolo do agente público em relação ao dano moral causado à vítima pelo Estado é imprescindivel, como também a existência da própria violação dos bens imateriais protegidos constitucionalmente (honra, vida privada, intimidade e imagem).

O direito à indenização por dano moral deve fundar-se no art. 186 do Código Civil, onde o autor precisará provar o ato culposo do agente, o nexo causal entre o ato e o resultado, bem como o prejuízo decorrente. Significa dizer que, em princípio, para o autor conseguir êxito na causa indenizatória tem o ônus e a incumbência de provar a ocorrência dos três requisitos retrocitados, tudo de acordo com o art. 333, inciso I, do Código de Processo Civil brasileiro.

Importante registrar que não existe lugar na ação de indenização pela responsabilidade objetiva para discutir aspectos subjetivos, com ampla instrução processual, provas, contraditório e defesa, Que envolve a responsabilidade por dano moral, o que, por essa razão. a torna incompatível para a apuração e avaliação dessa espécie de dano.

Além do mais, se o agente público supostamente causador do dano moral não participa da relação processual, haja vista Que não existe previsão constitucional e legal de denunciação da lide ao mesmo, e o próprio Poder Público está coartado a somente discutir aspectos restritos, como a culpa exclusiva da vítima, força maior e caso fortuito, não pode haver espaço para o pleito de reparação de dano moral na ação por responsabilidade objetiva, o Que deve ser buscada, por conseguinte, em outra ação com fundamento na responsabilidade subjetiva.

Para corroborar com o acima exposto, veja-se a posição jurisprudencial do ST): ${ }^{30}$

CIVIL E PROCESSUAL CIVIL. DANO MORAL. AGRESSÕES POR SEGURANÇAS DE SHOPPING CENTER. INDENIZAÇÃO. QUANTUM. HONORÁRIOS. CONDENAÇÃO. OBSERVÂNCIA AO ART. 21 . CPC. RECURSO DESACOLHIDO.

1-A indenizaçăo deve ser fixada em termos razoáveis, não se justificando Que a reparação venha a constituir-se em enriquecimento indevido, com manifestos abusos e exageros, devendo o arbitramento operar com moderação, proporcionalmente ao grau de culpa e ao porte econômico das partes, orientando-se o juiz pelos critérios sugeridos pela doutrina e pela jurisprudência, com razoabilidade, valendo-se de sua experiência e do bom senso, atento a realidade da vida e às peculiaridades de cada caso. Ademais, deve ela contribuir para desestimular o ofensor a repetir o ato, inibindo sua conduta antijurídica.

30 Resp n 215.607, RJ, Relator Ministro Salvio de Figueiredo Teixeira, julgado ocorrido em 17/08/1999, publicado no D| $13 / 09 / 1999$. 
II - Diante dos fatos da causa, razoável a indenização arbitrada pelo Tribunal de origem, levando-se em consideração não só a desproporcionalidade das agressões pelos seguranças como também a circunstâncias relevante de Que os shoppings centers săo locais freqüentados diariamente por milhares de pessoas e famílias.

III - Em face dos manifestos e freqüentes abusos na fixação do Quantum indenizatório, no campo da responsabilidade civil, com maior ênfase em se tratando de danos morais, lícito é ao Superior Tribunal de Justiça exercer o respectivo controle.

IV - Calculados os honorários sobre a condenação, a redução devida pela sucumbência parcial nela foi considerada.

Frente aos termos expressos na ementa do acórdão referenciado, a Qual muito bem sintetizou a fundamentação constante do voto vencedor, percebe-se Que, efetivamente, a forma de apuração da responsabilidade objetiva é totalmente inadequada para a averiguação e fixação da indenização por dano moral, porQuanto a análise dos aspectos subjetivos, Que nesse caso exige, como o grau de culpa, as peculiaridades do caso, as circunstâncias Que ocorreu o dano, e outros detalhes, refogem por demais à alçada do rito restrito da apuração objetiva. O próprio ônus da prova do fato constitutivo do direito do autor da ação de indenização por dano moral tem uma diferença substancial em relação à ação de indenização patrimonial pela teoria do risco administrativo adotada pela responsabilidade obietiva.

Considera-se, assim, Que a apuração da existência de dano moral deve passar, à semelhança do Que ocorre Quando houver dano decorrente de uma omissão do Estado, pela aplicação dos princípios e regras oue disciplinam a responsabilidade subjetiva. ${ }^{31}$

\section{CONSIDERAÇÕES FINAIS}

Com o exposto acima, espera-se ter contribuindo, de alguma forma, para aumentar, ainda mais, a inQuietude em relação ao tão polêmico assunto, Que é a indenização por dano moral, principalmente quando a ação é ajuizada contra o Poder Público, seja por pessoa Que não Faça parte da Administração Pública, seja por agente público.

Ao Que parece, a ação indenizatória por dano moral não pode aproveitar se do rito processual que segue a ação de reparação por dano patrimonial à luz da responsabilidade objetiva, pela teoria do risco administrativo, poreuanto nesta, o Estado somente pode discutir aspectos restritos para eximir-se da obrigação de indenizar, Que é a culpa exclusiva ou concorrente da vítima, de terceiros, caso fortuito e força maior.

31 ANIOS. Luís Henrique Martins dos; JONE. Walter.Op. cit., p. 350. 
Por envolver diversos aspectos a serem considerados, inclusive para a fixação do Quantum debeatur do dano moral, é de considerar-se que a ação deve ser ajuizada com base no art. 186 do Código Civil, ou seja, com base na responsabilidade subjetiva, onde o autor terá o ônus de provar o fato constitutivo de seu direito nos termos do art. 333, inciso I, do Código de Processo Civil. Caso seja imputada a responsabilidade a algum agente público, este deverá participar da relação processual, na condição de litisdenunciado.

Quanto ao cabimento em si da indenização por dano moral, esta somente deverá ocorrer Quando o Estado, por meio de seus agentes, de fato, agredir os direitos fundamentais (a honra, a intimidade, a imagem e a vida privada) de forma evidente, antijurídica, a fim de não se transformar em um instrumento de enriquecimento sem uma justa causa. E Quando essa indenização ocorrer, precisará levar em conta todos os requisitos firmados pelo Superior Tribunal de Justiça no acórdão acima mencionado.

O pedido de indenização por dano moral envolvendo como vítima agente público deve merecer mais atenção do Poder Jurisdicional, haịa vista Que, na grande maioria dos casos, o suposto dano ocorreu pelas circunstâncias inerentes à própria atividade pública.

Além do mais, o agente público, ao tomar posse em cargo ou função pública, assume os riscos imanentes à sua atividade, não podendo, por isso, ser desconsiderados Quando da apreciação de pleito indenizatório por dano moral.

Outro relevante aspecto a considerar, Quando existir agente público ou sua família como vítima, refere-se que, na grande Quantidade dos casos, os valores imateriais reverenciados e destacados pelo Poder Público e a própria sociedade, Quando ocorrer um dano a esse agente, suplantam, em muito, algum outro suposto direito protegido constitucionalmente pela ação de indenização por dano moral, alegadamente violado.

Por fim, na seara do pleito de dano moral contra o Estado, deve ocorrer um cuidado todo especial, a fim de não haver uma supervalorização desses direitos fundamentais de primeira geração, prejudicando, com isso, políticas públicas voltadas a entender harmonicamente outras gerações de direitos fundamentais, Que exigem atuaçóes positivas por parte do Poder Público; e, inclusive, esse desequilíbrio, poder gerar, como alguns doutrinadores alertam, desarmonização social e não pacilicicação. 


\section{REFERÊNCIAS BIBLIOGRÁFICAS}

ANJOS, Lús Henrique Martins dos; IONE. Walter, Manual de direito administrativo. Porto Alegre: Livraria do Advogado, 2001.

ASSOCIAÇĀO BRASILEIRA DE NORMAS TÉCNICAS. NBR14.724 - informação e Documentação - Trabalhos Acadêmicos - Apresentação. Rio de laneiro: Atual, 2002.

BRASIL. Constituição (1988). 4. ed. Rio de laneiro: DP\&A Editora, 1999.

DINIZ, Maria Helena. Curso Direito Civil Brasileiro. São Paulo: Saraiva, 2003, v. 17, p. 40.

ERPEN, Décio Antônio. A indústria do dano moral. Zero Hora. Porto Alegre, 10 out. 1998.

FURASTÉ, Pedro Augusto. Normas Técnicas para o Trabalho Cientifico: explicitação das Normas da ABNT. I3. ed. Porto Alegre: s.n., 2004. 1997.

MEIRELLES, Hely Lopes. Direito administrativo brasileiro. 22. ed. São Paulo: Malheiros,

MELLO. Celso Antonio Bandeira de. Curso de Direito Administrativo. São Paulo: Malheiros, 1997.

MORAES. Alexandre de. Direito constitucional. 5. ed. São Paulo: Atlas, 1999.

PIETRO, Maria Sylvia Zanella Di. Direito administrativo. [0. ed. São Paulo: Atlas, 1999.

SARLET. Ingo Wolfgang. A eficácia dos direitos fundamentais. Porto Alegre: Livraria do Advogado, 1998.

SILVA, José Afonso da. Curso de direito constitucional positivo. 13. ed. São Paulo: Malheiros, 1997.

SOARES. Mário Lúcio Quintão Soares. Direitos fundamentais do homem nos textos constitucionais brasileiro e alemão. Revista de Informação Legislativa, Brasília, v. 29, n. 1 I 5 , p. 85 I 38 , jul./set. 1992.

SOUZA, Alvaro Couri Antunes. O valor da causa nas açôes indenizatórias por danos morais. Revista dos Tribunais, São Paulo, v. 90, n. 783, p. 183-196, jan. 2001.

THEODORO JÚNIOR. Humberto. Curso de direito processual civil. 20. ed. Rio de laneiro: Forense, 1997.

TÔRRES. Heleno Taveira. O princípio da responsabilidade objetiva do estado e a teoria do risco administrativo. Revista de Informação Legislativa, Brasilia, v. 32, n. 126, p. 23 \}-243 abr./jun. 1995.

VENOSA, Silvio de Salvo. Direito civil. Contratos em espécie e responsabilidade civil. São Paulo: Atlas, 200 I, v. 3. 